\title{
Komunikasi Nonverbal Guru dalam Meningkatkan Prestasi Belajar Siswa di SMP Muhammadiyah 7 Medan
}

\author{
Sugiarno, Rahmanita Ginting*) \\ SMP Muhammadiyah 13 Medan, Kota Medan dan Program Studi Magister Ilmu Komunikasi, Universitas \\ Muhammadiyah Sumatera Utara, Indonesia \\ koresponden: sugiarno@yahoo.co.id
}

\begin{abstract}
ABSTRAK
Penelitian ini bertujuan untuk menjelaskan komunikasi nonverbal guru berkaitan dengan kinesik, proksemik, dan paralinguistik dalam meningkatkan prestasi belajar siswa di SMP Muhammadiyah 7 Medan. Penelitian ini menggunakan metode penelitian deskriptif kualitatif, yaitu mendeskripsikan pendapat objek yang diteliti berdasarkan fakta yang ada di lapangan mengenai komunikasi nonverbal guru dalam meningkatkan prestasi belajar siswa di SMP Muhammadiyah 7 Medan. Subjek yang diteliti dalam penelitian ini adalah guru. Data dikumpulkan melalui wawancara, observasi, dan dokumentasi. Data yang telah dikumpulkan peneliti akan dianalisis dengan tahapan reduksi data, display data, dan kesimpulan. Lokasi penelitian dilakukan di SMP Muhammadiyah 7 Medan. Penelitian dilakukan dari Februari 2015 sampai Maret 2016. Hasil penelitian menyebutkan bahwa kinesik yang meliputi gesture, ekspresi wajah, kontak mata dan penampilan dari guru menunjukkan hal yang sangat penting dalam memperkuat informasi tentang pelajaran yang disampaikan guru.
\end{abstract}

Kata Kunci: Komunikasi Nonverbal, Guru, Gesture

\begin{abstract}
This study aims to explain the nonverbal communication of teachers related to kinesics, proxemic, and paralinguistic in improving student learning achievement at SMP Muhammadiyah 7 Medan. This study uses a descriptive qualitative research method, which describes the opinion of the object under study based on facts in the field regarding teacher nonverbal communication in improving student learning achievement at SMP Muhammadiyah 7 Medan. Subjects examined in this study were teachers. Data collected through interviews, observations, and documentation. The data collected by researchers will be analyzed by the stages of data reduction, data display, and conclusions. The location of the study was conducted at SMP Muhammadiyah 7 Medan. The study was conducted from February 2015 to March 2016. The results of the study stated that kinesik which includes gestures, facial expressions, eye contact and appearance of the teacher showed that it was very important in strengthening information about the lessons delivered by the teacher.
\end{abstract}

Keywords: Nonverbal Communication, Teacher, Gesture 


\section{Pendahuluan}

Pembangunan nasional di bidang pendidikan adalah upaya mencerdaskan kehidupan bangsa dan meningkatkan kualitas manusia Indonesia dalam mewujudkan masyarakat yang maju, adil, dan makmur berdasarkan pancasila dan undang-undang Dasar 1945, yang memungkinkan warganya mengembangkan diri sebagai manusia Indonesia seutuhnya. Sistem pendidikan nasional diselenggarakan melalui dua jalur yaitu jalur pendidikan sekolah, dan jalur pendidikan luar sekolah. Pendidikan memberi kesan dan pengalaman kepada manusia yang dengan kesan dan pengalaman itu pula ia akan memiliki sejumlah pengetahuan yang kelak akan menentukan kualitas manusia itu sendiri. Semakin banyak pengetahuan dan pengalaman yang dimilikinya maka akan semakin baiklah kualitasnya.

Dalam proses pembelajaran yang mengacu pada aktivitas guru dan siswa saat pelaksanaan program pengajaran di dalam ruang kelas, disinilah guru memegang peranan sentral, hal ini dikarenakan guru memiliki tiga tugas utama yaitu, merencanakan, melaksanakan dan mengevaluasi program pengajaran. Untuk mencapai tujuan tersebut, maka pemerintah mengeluarkan kebijakandengan menetapkan Undang-Undang N0. 20 Tahun 2003 tentang Sistem Pendidikan Nasional Bab II pasal 3 yang berbunyi (Lisna, 2013:123): Pendidikan Nasional berfungsi mengembangkan kemampuan dan membentuk watak serta peradaban bangsa yang bermartabat dalam rangka mencerdaskan kehidupan bangsa, bertujuan untuk berkembangnya potensi peserta didik agar menjadi manusia yang beriman dan bertaqwa kepada Tuhan Yang Maha Esa, berakhlak mulia, sehat berilmu, cakap, kreatif, mandiri dan menjadi warga Negara yang demokratis serta bertanggung jawab.

Dalam proses pendidikan sering kita jumpai kegagalan-kegagalan, hal ini biasanya dikarenakan lemahnya sistem komunikasi. Untuk itu, pendidik perlu mengembangkan pola komunikasi yang efektif dalam proses belajar mengajar. Komunikasi pendidikan yang penulis maksudkan disini adalah hubungan atau interaksi antara pendidik dengan peserta didik pada saat proses belajar mengajar berlangsung atau dengan istilah lain yaitu hubungan aktif antara pendidik dengan peserta didik. Sebagai seseorang yang memiliki posisi strategis dalam kegiatan pembelajaran, guru harus memiliki beberapa kompetensi yang meliputi kompetensi pedagogik, kompetensi kepribadian, kompetensi sosial, dan kompetensi profesional. Yang berkaitan dengan kompetensi pedagogik yaitu kompetensi yang berhubungan langsung dengan keterampilan guru dalam kegiatan belajar mengajar. Dengan keterampilan guru dalam menciptakan iklim komunikatif diharapkan siswa dapat berpartisipasi aktif untuk mengeluarkan pendapatnya, mengembangkan imajinasinya dan daya kreativitasnya. Tentu komunikasi guru dan siswa yang dimaksud adalah dalam kegiatan pembelajaran tatap muka baik secara verbal maupun non verbal, baik secara individual maupun kelompok dan dibantu dengan media atau sumber belajar (Lisna, 2013:123).

Komunikasi sangat dibutuhkan pada saat proses belajar mengajar sedang berlangsung, apalagi pada saat pelaksanaan program pengajaran yang telah disusun sebelumnya juga membutuhkan komunikasi. Dengan demikian seorang guru harus dapat memilih serta mengembangkan media dalam pembelajaran, sehingga dapat mengelola interaksi belajar mengajar secara efektif.

Proses komunikasi dapat terjadi apabila ada interaksi antar manusia dan penyampaian pesan untuk mewujudkan motif komunikasi. Terdapat beberapa tahapan dalam proses komunikasi yakni; penginterpretasian, penyandian, pengiriman, perjalanan, penerimaan, penyandian balik, penginterpretasian (Vardiansyah, 2004: 36).

Sebagai contoh keefektifan komunikasi dalam proses belajar mengajar matematika dapat terjadi, apabila siswa mengerti dan memahami apa yang disampaikan oleh guru, serta adanya timbal balik baik antara guru dengan siswa atau sebaliknya. Kemudian siswa diharapkan terdorong untuk belajar matematika dan mendapatkan nilai pada tingkat yang optimal. Begitu juga dengan mata pelajaran yang lainnya diharapkan komunikasi yang terjalin dapat bersifat dua arah sehingga ada feedback serta efek yang muncul sebagai evaluasi dalam penilaian apakah komunikasi yang sudah berjalan efektif atau tidak. 
Selain proses komunikasi secara verbal, penggunaan komunikasi nonverbal juga penting dalam proses belajar dan mengajar antara guru dan siswa, karena dalam proses belajar mengajar penggunaan komunikasi nonverbal yang berupa kinesik (kontak mata, ekspresi wajah, gerakisyarat, postur dan sentuhan), paralinguisltik (tinggi rendahnya suara, volume, kecepatan, dan kualitas suara), dan proksemik, (pemanfaatan ruang informal) merupakan salah satu faktor yang dapat meningkatkan prestasi belajar siswa. Sebagai contoh pada saat seorang guru berbicara namun tidak menggunakan gerak tubuh dan ekspresi wajah dan hanya berdiri mematung saja, maka siswa yang memperhatikannya tidak akan merasa senang sehingga keinginan belajarnya pun akan surut.

SMP Muhammadiyah 7 Medan merupakan salah satu sekolah yang lebih mengarah pada nilai keislaman, namun pada kurikulumnya sama dengan sekolah SMP pada umumnya hanya saja dalam mempelajari nilai agama jauh lebih banyak dibandingkan pada sekolah umum lainnya. Proses belajar mengajar di sekolah SMP Muhammadiyah ini sebenarnya sudah cukup baik, namun ada beberapa murid yang tidak mengalami kemajuan dalam prestasi belajarnya.

Hal ini membuktikan bahwa proses komunikasi secara verbal yang berlangsung kurang efektif karena komunikasi yang digunakan belum menyentuh atau mempengaruhi siswa dalam memahami dan mengerti terhadap mata pelajaran yang telah diberikan oleh guru. Dikarenakan komunikasi secara verbal masih belum efektif dalam mempengaruhi siswa dalam meningkatkan prestasi belajarnya maka komunikasi nonverbal pun terasa sangat penting digunakan oleh guru agar komunikasi dalam belajar mengajar menjadi lebih efektif. Apabila komunikasi yang terjalin sudah menjadi lebih efektif maka akan dapat meningkatkan prestasi belajar siswa.

Alasan peneliti memilih SMP Muhammadiyah 7 Medan sebagai objek penelitian karena berdasarkan pengamatan yang dilaksanakan di SMP Muhammadiyah 7 Medan peneliti melihat bahwa siswa lebih senang menunggu dan menerima informasi dibandingkan berfikir aktif dan saling memberi masukan seperti bertanya, menjawab pertanyaan, memberi tanggapan dan menyampaikan ide-ide, sehingga yang terjadi guru lebih dominan dalam kegiatan pembelajaran, karena komunikasi yang terjadi hanya satu arah tanpa ada timbal balik dari siswa.

Beranjak dari persoalan yang dikemukakan di atas dapat dipahami bahwa begitu pentingnya efektifitas berkomunikasi dalam proses belajar mengajar di sekolah, terutama pada komunikasi nonverbal karena tanpa adanya komunikasi nonvebal siswa tidak akan nyaman untuk belajar. Ketidaknyamanan yang dialami siswa akan menyebabkan siswa malas belajar. Berdasarkan hal tersebut, maka menjadi pertanyaan bagi peneliti bagaimanakah komunikasi nonverbal guru dapat meningkatkan prestasi belajar siswa di sekolah? Berdasarkan pertanyaan ini, maka perlu dilakukannya penelitian tentang komunikasi nonverbal guru di sekolah Muhammadiyah 7 Medan dengan rumusan masalah penelitian bagaimanakah komunikasi nonverbal guru berkaitan dengan kinesik, proksemik dan paralinguistik dalam meningkatkan prestasi belajar siswa di SMP Muhammadiyah 7 Medan?Bagaimanakah komunikasi nonverbal guru berkaitan ik dalam meningkatkan prestasi belajar siswa di SMP Muhammadiyah 7 Medan

\section{Fungsi Pesan Nonverbal}

Mark L. Knapp menyebutkan bahwa ada lima fungsi pesan nonverbal, yaitu : (1) Repetisi yaitu mengulang kembali gagasan yang sudah disajikan secara verbal, misalnya menggelengkan kepala berkali-kali tanda penolakan, (2) Substitusi yaitu mengganti lambang-lambang verbal, misalnya mengangguk-anggukan kepala tanda persetujuan, (3) Kontradiksi yaitu menolak pesan verbal atau memberikan makna yang lain terhadap pesan verbal, misalnya mencibirkan bibir tanda kita memuji atau sebaliknya, (4) Komplemen yaitu melengkapi dan memperkaya makna pesan nonverbal, misalnya perubahan air muka yang menunjukkan tingkat penderitaan yang tidak terungkap dengan kata-kata, (5) Aksentuasi yaitu menegaskan pesan verbal atau menggarisbawahinya, misalnya memukulkan tangan ke suatu benda tanda kita marah (Rakhmat, 2007: 287). Dale G. Leather penulis Nonverbal Communication Systems menyebutkan enam alasan mengapa pesan nonverbal sangat penting (Rakhmat, 2007: 287-289), yakni: pertama, faktorfaktor nonverbal sangat menentukan makna dalam komunikasi interpersonal. Ketika kita 
berkomunikasi tatapmuka, kita banyak menyampaikan gagasan dan pikiran kita lewat pesan-pesan nonverbal. Pada gilirannya orang lain pun lebih banyak membaca pikiran kita lewat petunjukpetunjuk nonverbal . Kedua, perasaan dan emosi lebih cermat disampaikan lewat pesan nonverbal ketimbang pesan verbal. Ketiga, pesan nonverbal menyampaikan makna dan maksud yang relatif bebas dari penipuan, distorsi, dan kerancuan. Pesan nonverbal jarang dapat diatur oleh komunikator secara sadar. Misalnya ketika seorang wanita mengatakan "tidak" tetapi sesungguhnya gerakan tubuhnya mengatakan "ya".

Dalam situasi komunikasi yang disebut "double binding" ketika pesan nonverbal bertentangan dengan pesan verbal orang akan bersandar pada pesan nonverbal. Keempat, pesan nonverbal mempunyai fungsi meta komunikatif yang sangat diperlukan untuk mencapai komunikasi yang berkualitas tinggi. Fungsi meta komunikatif artinya memberikan informasi tambahan yang memperjelas maksud dan makna pesan. Kelima, pesan nonverbal merupakan cara komunikasi yang lebih efisien dibandingkan dengan pesan verbal. Dari segi waktu, pesan verbal sangat tidak efisien. Dalam paparan verbal salalu terdapat redudansi (lebih banyak lambang dari yang dperlukan), repitisi, ambiguity (kata-kata yang berati ganda), dan abstraksi. Diperlukan lebih banyak waktu untuk mengungkapkan pikiran kita secara verbal daripada secara nonverbal. Keenam, pesan nonverbal merupakan sarana sugesti yang paling tepat. Ada situasi komunikasi yang menuntut kita untuk mengungkapkan gagasan atau emosi secara tidak langsung. Sugesti di sini dimaksudkan menyarankan sesuatu kepada orang lain secara implisit (secara tersirat). Sugesti paling efektif disampaikan melalui pesan-pesan nonverbal.

Menurut Verderber komunikasi nonverbal memiliki lima fungsi (dalam Budyatna \& Ganiem, 2011: 115-118): Pertama, Melengkapi informasi. Kebanyakan informasi atau isi sebuah pesan disampaikan secara nonverbal. Isyarat-isyarat nonverbal dapat mengulang, mensubstitusi, menguatkan atau mempertentangkan pesan verbal kita. Kita dapat menggunakan isyarat-isyarat nonverbal untuk mengulangi apa yang telah kita katakan secara verbal. Kedua, Mengatur interaksi. Kita mengelola sebuah interaksi melalui cara-cara yang tidak kentara dan kadang-kadang melalui isyarat nonverbal yang jelas. Kita gunakan perubahan atau pergeseran dalam kontak mata, gerakan kepala, bergeser dalam sikap badan, mengangkat alis, menganggukkan kepala memberitahukan pihak lain kapan boleh melanjutkan, mengulang, menguraikan, bergegas atau pun berhenti. Ketiga, Mengekspresikan atau menyembunyikan emosi dan perasaan.

Secara alternatif kita dapat gunakan perilaku nonverbal untuk menutupi perasaan kita yang sebenarnya. Namun demikian, lebih sering daripada tidak, kita menunjukkan emosi kita yang sebenarnya secara nonverbal daripada menjelaskan emosi kita dengan kata-kata. Adakalanya kita mencoba menyembunyikan emosi dan perasaan kita, tetapi secara tidak sengaja suka bocor atau terbaca orang lain. Keempat, Menyajikan sebuah citra. Manusia mencoba menciptakan kesan mengenai dirinya melalui cara-cara dia tampil dan bertindak. Kebanyakan pengelolaan kesan terjadi melalui saluran nonverbal. Manusia dapat secara hati-hati mengembangkan citra melalui pakaian, merawat diri, perhiasan, dan milik pribadi lainnya. Orang tidak hanya menggunakan komunikasi nonverbal untuk mengkomunikasikan citra pribadi, tetapi dua orang dapat menggunakan isyarat-isyarat nonverbal untuk menyajikan citra atau identitas hubungan. Kelima, Memperlihatkan kekuasaan dan kendali. Banyak perilaku nonverbal merupakan isyarat dari kekuasaan, terlepas dari apakah mereka bermaksud menunjukkan kekuasaan dan kendali. Coba bayangkan bagaimana manajer tingkat tinggi memperlihatkan status dan bagaimana karyawan bawahan mengakui status itu melalui perilaku nonverbal.

\section{Penggunaan Kinesik}

Kinesik adalah persepsi yang didasarkan pada gerakan orang lain yang ditunjukkan kepada kita. Beberapa penelitian membuktikan persepsi yang cemat tentang sifat-sifat dari pengamatan kinesik. Dalam bidang ini dapat diperinci dalam beberapa komponen: (1) bahasa isyarat (gestures); (2) ekspresi wajah; (3) kontak mata; dan (4) tampilan. 1.Bahasa syarat (Gestures): Gestures menjadi monopoli simbol yang dimiliki oleh komunikasi dalam hampir semua kebudayaan, 
sedangkan bahasa verbal adalah sesuatu yang spesifik dalam kebudayaan, maka simbol kata-kata dapat berbeda antar semua kebudayaan. Dalam kasus gestures, maka mungkin sekali anda menemukan isyarat tangan dalam makna yang sama meskipun kebudayaannya berbeda, namun simbol kata-kata tangan akan berbeda di antara bahasa. (Liliweri, 2011: 384) Manusia berbeda dalam jumlah gerak isyarat yang digunakan untuk mengikuti ucapan verbalnya. Ada orang yang "berbicara dengan tangannya" jauh lebih banyak dari yang lainya. Beberapa gerak isyarat yang dinamakan emblem dapat berdiri sendiri atau sebagai pengganti sepenuhnya bagi kata-kata. Gerak isyarat seorang pembonceng atau yang minta tumpangan merupakan emblem yang tidak perlu diikuti dengan kata-kata. Beberapa gerak isyarat dinamakan adopters terjadi tanpa disadari untuk merespon kebutuhan fisik. Misalnya, menggaruk-garuk kepala karena gatal, membetulkan letak kaca mata, menggosok-gosokkan kedua telapak tangan karena dingin. Anda tidak bermaksud untuk mengkomunikasikan sebuah pesan dengan gerakan isyarat tersebut, tetapi orang lain yang memperhatikannya bisa saja memberikan makna kepada hal-hal tersebut (Budyatna \& Ganiem, 2011: 128).

2.Ekspresi Wajah

Ekspresi wajah dapat dijadikan sebagai informasi kepada orang lain. Berbagai penelitian mencatat hampir 300.000 lebih ekspresi wajah yang maknanya berbeda satu sama lain (Liliweri, 2011: 385). Di samping itu juga ekspresi wajah mempunyai arti penting dalam menyumbang penampilan seseorang secara keseluruhan, ekspresi wajah juga bisa menjadi sumber pesan dirinya sendiri, menyediakan informasi yang terbaik tentang kondisi emosi seorang individu, kegembiraan, ketakutan, terkejut, kesedihan, marah, merendahkan dan ketertarikan. Para peneliti juga percaya bahwa peran dari wajah dalam kaitannya dengan emosi atau perasaan adalah berlaku umum pada seluruh manusia. Dalam menguraikan tentang apa yang disebut sebagai "teori neurocultural tentang ekspresi wajah," Paul Ekman (dalam Ruben \& Stewart, 2013: 179) menjelaskan: "Hal universal mengenai emosi melalui ekspresi pada raut wajah adalah gerakan otot wajah tertentu ketika emosi yang diberikan muncul". Kondisi dan peristiwa tertentu yang memicu emosi bervariasi secara individual dan secara budaya. Dan adat istiadat seta aturan mengarahkan aturan-aturan tampil bagi emosi tertentu juga dapat saja berbeda antar satu orang ke orang yang lain, serta dari satu budaya ke budaya yang lain.

3. Kontak Mata

Kontak mata adalah koneksi visual yang menggambarkan salah satu pihak menatap ke dalam mata pihak lain. Tatapan mata rupanya merupakan pesan yang paling intens karena sangat menonjolkan emosional. Kontak mata punya dua fungsi komunikasi nonverbal. Pertama, fungsi pengatur, untuk memberi tahu orang lain apakah kita akan melakukan hubungan dengan orang itu atau menghindarinya. Ketika kita berada dalam lief, misalnya kita memberi tahu mereka bahwa kita lebih suka tidak berbicara dengan tidak melihat mata mereka. Jika kita ingin memecahkan kebekuan itu, kita menggunakan mata kita untuk berhubungan, baik sebelum atau serempak dengan pesan verbal kita. Kedua, fungsi ekspresif, memberi tahu orang lain bagaimana perasaan kita terhadapnya. Pria menggunakan lebih banyak kontak mata dengan orang yang mereka sukai, meskipun menurut penelitian perilaku ini kurang ajeg (kurang pas/cocok) di kalangan wanita (Mulyana, 2008: 373).

4. Tampilan

Bagaimana kita berpakaian, warna dan model pakian, bagaimana kita menyisir rambut, tipe tubuh, dan bagaiman tubuh kita ditampilkan merupakan unsur-unsur tampilan (posture) yang dapat menunjukkan sebuah pesan. Simbol nonverbal seperti itu erat kaitannya dengan penilaian budaya, misalnya seni, estetika, atau keindahan. Jadi interpretasi makna terhadap tampilan tubuh memang sangat berbeda-beda dari satu kebudayaan ke budayaan yang lain (Liliweri, 2011: 387)

Menurut Ray Birdwhistell (dalam Littlejohn \& Foss, 2014: 159), seorang antropolog yang tertarik dengan bahasa, beliau menggunakan linguistik sebagai model untuk karya kinesiknya. Dalam bukunya, Kinesics and Context, Birdwhistell memberikan tujuh asumsinya yang menjadi dasar teori dalam bahasa tubuh. 


\section{Penggunaan Proksemik}

Studi mengenai penggunaan ruangan oleh manusia dinamakan proksemik yang berasal dari bahasa Inggris "proxemics". Proksemik mencakup studi mengenai bagaimana orang menggunakan ruang dalam percakapan mereka termasuk persepsi yang ditimbulkannya. Secara khusus, proksemik mengacu pada penggunaan ruang (space) dalam komunikasi yaitu studi mengenai bagaimana manusia secara tidak sadar membuat struktur terhadap ruang dimana ia berada. Judee K. Burgoon (dalam Morissan, 2010: 127) mendasarkan teorinya pada pemikiran bahwa manusia memiliki dua kebutuhan yang saling bersaing yaitu kebutuhan afiliasi dan kebutuhan ruang personal. Ruang personal didefinisikan sebagai : An invisible, variable volume of space surroundingan individual which defines that individual's preferred distance from others" (volume ruang yang tidak terlihat dan berubah-ubah disekitar individu yang menentukan jarak yang disukai individu bersangkutan terhadap individu lainnya).

Burgoon dan para pendukung teori ini percaya bahwa manusia memiliki keinginan untuk berdekatan dengan orang lain tetapi pada saat yang sama juga ingin menjaga jarak dengan orang lain. Pada umumnya orang tidak suka menyendiri dan terisolasi, namun ada kalanya orang membutuhkan privasi. Menurut Edward Hall (dalam Littlejhon \& Foss, 2014: 161-162) metode jarak ini digunakan dalam interaksi, sangat bermasalah dengan kebudayaan. Pengertian yang berbeda penting bagi budaya yang berbeda. Di beberapa negara seperti Amerika, pandangan dan pendengaran yang berkuasa, di tempat lain seperti budaya Arab, penciuman juga penting. Beberapa kebudayaan bergantung pada sentuhan lebih dari yang lainnya. Pada umumnya, pengertian yang menonjol dari sebuah kebudayaan biasanya menentukan jarak yang digunakan dalam kebudayaan tersebut. Hall mendefinisikan tiga jenis dasar jarak antara lain: ruang karakteristik terbatas terdiri dari benda-benda yang tidak dapat dipindahkan, seperti dinding dan kamar, ruang karakteristik semi terbatas meliputi objek yang dapat bergerak seperti furniture dan ruang informal adalah daerah pribadi sekitar tubuh yang menjalar dengan tubuh seseorang dan menentukan jarak antarpribadi diantara manusia. Secara terperinci proksemik dapat dibagi pada tiga bagian (Liliweri, 2011: 387-391) yaitu :

1. Proksemik jarak: merupakan bahasa jarak sebagai simbol komunikasi yang paling sensitif. Jarak antara orang dapat digolongkan sebagai jarak sahabat intim, jarak asal kenal, atau jarak romantis.

2. Proksemik ruang.

Ada beberapa aspek yang berkaitan dengan proksemik ruang, yaitu:

a. Ukuran ruang. Di sebagian besar kantor, baik pemerintah maupun swasta, ukuran ruang menentukan status dan kedudukan seseorang. Seseorang yang mempunyai kedudukan lebih tinggi mempunyai ruang kerja yang lebih besar daripada yang berkedudukan lebih rendah.

b. Hawa atau udara dalam ruangan. Pada umumnya seseorang yang mempunyai kekuasaan lebih tinggi mempunyai ruang kerja yang lebih sejuk, ruang ini dipasang pendingin atau pemanas sesuai kebutuhan iklim setempat.

c. Warna. Menentukan dan mewakili pribadi orang yang duduk atau berdiri di dalam ruangan. Ruang berwarna cerah menggambarkan kegembiraan, suka cita, dan bersahabat.

d. Pencahayaan. Juga menggambarkan suasana dalam ruangan. Untuk kepentingan pekerjaan kantor dibutuhkan pencahayaan yang cukup, kecuali ruang untuk minum kopi memerlukan pencahayaan yang remang-remang.

e. Jangkauan ruangan. Ini berkaitan dengan kemudahan untuk mencapai ruangan. Pada umumnya ruang kerja Humas terletak dekat pintu masuk utama suatu kantor.

f. Bentuk dan tata letak ruang. Bentuk atau tata letak ruang yang memberikan simbol atau tanda bahwa orang dapat menggunakan ruang sesuai dengan kemauannya.

3. Proksemik waktu.

Proksemik waktu sering disebut kronemik atau pandangan tentang waktu. Sekurang-kurangnya dikenal dua konsep waktu, yaitu: 
a. Monokronik, yakni pandangan bahwa waktu selalu bergerak secara linear, waktu akan terus bergerak seperti deret hitung, pergantian waktu merupakan sesuatu yang tidak terlalu luar biasa. Ada hubungan antara aktivitas dan konsep waktu monokronik. Mereka yang berbudaya monokromik hanya mengerjakan satu tugas dan diikuti oleh tugas lain setelah tugas pertama selesai.

b. Polikronik, adalah pandangan terhadap waktu yang sangat berharga, waktu kini tidak terulang lagi, dalam bisnis selalu terungkap time is money.

Kaitannya dengan proksemik waktu, dapat dijelaskan bahwa "waktu" menentukan kedekatan sosial dan personal antara dua orang dalam komunikasi personal, karena itu waktu dapat menggambarkan sebuah peristiwa yang dapat memberikan makna, maksud, dan tujuan tertentu. Waktu menentukan kecepatan tanggapan dan reaksi kita terhadap percakapan lisan dengan seseorang. Rata-rata budaya Amerika serikat mengharapkan tanggapan segera ketika berbicara kepada kita, jika kita terus berdiam diri maka akan membuatnya merasa tidak nyaman.

Dalam beberapa kebudayaan tertentu kebanyakan orang mungkin mengharapkan keheningan sebelum merespon suatu pendapat, ini berati bahwa jika kita merespon pembicaraan seseorang terlalu cepat dapat menunjukkan bahwa kita kaget dan kurang memperhatikan si pembicara. Bagaimana kita mempersepsi dan memperlakukan waktu secara simbolik menunjukkan sebagian dari jati diri kita, siapa diri kita dan bagaimana kesadaran kita akan lingkungan kita. Bila kita selalu menepati waktu yang dijanjikan, maka komitmen pada waktu memberikan pesan tentang diri kita.

\section{Penggunaan Paralinguistik Dalam Komunikasi Nonverbal.}

Paralanguage atau vocalics adalah "suara" nonverbal apa yang kita dengar bagaimana sesuatu dikatakan. Kita mulai dengan menjelaskan empat karakteristik vokal yang meliputi paralanguage dan kemudian membicarakan bagaimana kesimpulan-kesimpulan vokal dapat menggangu arus pesan. Di samping itu pada waktu kita bercakap-cakap maka kita selalu melakukan perubahan atas tekanan suara terhadap kata-kata, membuat jeda antara satu kata dan kata lain, mengatur tempo atau irama, atau menyela kata-kata dalam tindakan agar kata-kata itu lebih bermakna. Paralinguistik meliputi setiap penggunaan suara sehingga dia bermanfaat kalau kita hendak menginterpretasikan simbol verbal. Sebagai contoh, orang-orang Muangthai merupakan orang yang rendah hati mirip dengan orang jawa yang tidak mengungkapkan kemarahan dengan suara yang keras. Mengkritik orang lain biasanya tidak diungkapkan secara langsung tetapi dengan anekdot, ini beda dengan orang Batak dan Timur yang mengungkapkan segala sesuatu dengan suara yang keras (Liliweri, 2011: 393 ):

\section{Bentuk Vokal}

Salah satu fokus pembahasan kita tentang paralinguistik adalah tentang hal-hal yang terkait dengan suara (vocalics) seperti pesan pendengaran, pesan selain dari kata-kata, yang diciptakan dalam proses pembicaraan. Vokalik, yang meliputi tinggi rendah suara, kecepatan berbicara, irama, batuk, tertawa, sengau, berhenti, bahkan keheningan, adalah sumber-sumber pesan yang sangat penting dalam komunikasi tatap muka (Ruben \& Stewart, 2013: 175).

\section{Volume}

Volume merupakan kerasnya atau lembutnya nada. Mengingat ada orang yang mempunyai suara yang besar atau nyaring yang bisa terdengar pada jarak jauh, lainnya secara normal bersuara lembut. Namun demikian, tanpa memerhatikan volume suara mereka yang normal, orang mempunyai volume suara yang berbeda bergantung pada situasi dan topik pembicaraan. Misalnya, orang berbicara keras apa bila ingin didengar dalam keadaan gaduh atau berisik, mereka bisa menaikkan volume suaranya apabila sedang marah, atau berbicara lebih lembut dalam keadaan romantis atau jatuh cinta.

3. Kecepatan

Kecepatan atau rate mengacu kepada kecepatan pada saat orang berbicara. Orang cenderung berbicara lebih cepat apabila sedang berbahagia, terkejut, gugup, atau sedang gembira. Berbicara 
lebih lambat apabila mereka sedang memikirkan jalan keluar penyelesaian, atau mencoba menegaskan pendiriannya.

4. Kualitas

Kualitas merupakan bunyi dari suara seseorang. Setiap suara manusia memiliki nada yang berbeda, beberapa suara bersifat serak atau parau, suara yang tidak enak atau tidak menyenangkan, suara yang bersifat nyaring, suara seperti tertahan di leher. Tambahan pula, masing-masing dari kita menggunakan kualitas yang sedikit berbeda mengenai suara untuk mengkomunikasikan dalam keadaan pikiran yang khusus. Sedangkan ada lagi yang disebut intonasi atau intonation merupakan jumlah mengenai macam, lagu, atau nada suara di dalam suara seseorang. Beberapa suara memiliki nada yang kecil dan bunyi yang monoton. Suara-suara lainnya penuh dengan nyanyian atau irama dan ada pula dengan suara kekanak-kanakan. Orang biasanya memilih untuk mendengarkan suara dengan jumlah yang sedang-sedang saja intonasinya (Budyatna \& Ganiem, 2011: 132).

\section{Metode}

Metode penelitian yang dilakukan dalam penelitian ini adalah pendekatan kualitatif, sedangkan tipe penelitian ini menggunakan tipe deskriptif kualitatif yang mana peneliti mendeskriptifkan wawancara mendalam terhadap subjek pelitian. Di sini peneliti bertindak selaku fasilitator dan realitas dikontruksi oleh subjek penelitian. Selanjutnya peneliti bertindak sebagai aktivis yang ikut memberi makna secara kritis pada realitas yang dikontruksi oleh subjek penelitian (Kriyantono, 2006: 389). Subjek dalam penelitian ini dilaksanakan pada SMP Muhammadiyah 7 Medan. SMP Muhammadiyah 7 Medan adalah Sekolah Menengah Tingkat Pertama (SLTP) yang berciri nasional dan agama yang diselenggarakan oleh Pimpinan Cabang Muhammadiyah Sidorame Barat bagian Majelis Pendidikan Dasar dan Menengah (Dikdasmen) yang posisinya di bawah naungan Dinas Pendidikan Kota Medan. Objek penelitian meliputi: (1) Komunikasi non verbal kinesik (2) Komunikasi non verbal proksemik, (3) Komunikasi non verbal paralinguistik yang dilakukan oleh guru di SMP Muhammadiyah 7 Medan. Dalam penelitian ini, peneliti memiliki beberapa kriteria dalam pemilihan informan, yaitu guru dan siswa-siswi SMP Muhammadiyah 7 Medan. Adapun guru yang masa kerjanya di atas lima tahun sebanyak 15 guru dan guru yang masa kerjanya di bawah lima tahun 10 guru, sehingga seluruh jumlah guru SMP muhammadiyah 7 sebanyak 25 guru yakni Yunizar (Y), Usril (U), dan Sutarno (S). Dan nama dari tiga siswa siswi tersebut antara lain; Novi Ramadhani Arif (NR), Khairani (K), dan Muhammad Rhenalds Al Amin (MR).

\section{Hasil dan Pembahasan}

Komunikasi nonverbal merupakan proses komunikasi yang dilakukan tanpa menggunakan bahasa ataupun kata-kata, tetapi biasanya proses komunikasi tersebut dilakukan dengan cara lain seperti bahasa tubuh, mimik wajah, sensitifitas kulit, dan lain-lain. Pada komunikasi verbal sendiripun seperti kata-kata baik lisan ataupun tulisan masih memiliki kekurangan dalam menyampaikan pesan kepada komunikannya, sehingga pesan-pesan yang bersifat nonverbal tentunya tetap dibutuhkan untuk memperjelas informasi-informasi yang disampaikan oleh komunikator agar komunikan dapat lebih memahami isi pesan tersebut, sehingga dapat memperkecil terjadinya kesalahan persepsi.

“...komunikasi nonverbal itu adalah komunikasi yang dilakukan tidak melalui suara ataupun mulut ataupun lisan tetapi adalah melalui gerak itulah yang setau saya..." (U), “...komunikasi nonverbal itu menurut saya merupakan komunikasi antar dua orang atau lebih yang tanpa menggunakan ee..bahasa lisan tetapi menggunakan isyarat tubuh..." (S) seperti yang telah diungkapkan dalam kutipan wawancara oleh $\mathrm{U}$ dan $\mathrm{S}$ di atas menyatakan bahwa komunikasi nonverbal merupakan menciptakan dan menukarkan pesan dengan tidak menggunakan kata-kata atau dengan kata lain bahwa seluruh proses komunikasi yang terjadi yang tidak ada hubungannya 
dengan kata-kata yang diucapkan atau dituliskan. Begitu juga yang diterangkan oleh NR, K dan MR yang menyatakan komunikasi nonverbal merupakan komunikasi dengan menggunakan isyarat tangan, mata ataupun hal-hal lainnya tanpa kata-kata baik itu lisan ataupun tulisan. Seperti kutipan wawancara di bawah ini: “...eee...kalau menurut saya komunikasi nonverbal itu adalah komunikasi yang dilakukan dengan cara gerakan contohnya isyarat mata, tangan, gerakan ataupun yang lainnya..." (NR) “...kalo komunikasi nonverbal adalah komunikasi itu tidak melihat apapun misalnya dengan bahasa tangan aja atau menggerakkan badan..." (K)

"...menurut saya komunikasi nonverbal itu komunikasi suatu komunikasi dimana komunikasi tersebut tidak menggunakan alat komunikasi yang biasa kita gunakan seperti isyarat dengan mata dan sebagainya..." (MR).

Dapat dicontohkan bahwa cara kita duduk, berjalan, berpakaian secara keseluruhan dapat menyampaikan informasi kepada orang lain. Setiap gerakan yang dilakukan dapat menyatakan asal usul, sikap, kesehatan dan bahkan keadaan psikologis seseorang. Contoh lainnya dengan gerakangerakan seperti mengerutkan alis, menggigit bibir, menunjuk dengan jari, tangan di pinggang, sampai pada melipat tangan di dada. Komunikasi nonverbal ternyata dibutuhkan dalam kegiatan belajar mengajar terutama pada lingkungan sekolah. Penguatan makna pada komunikasi verbal yang dilakukan oleh guru pada saat memberikan materi pelajaran di depan kelas merupakan hal yang penting dan dibutuhkan oleh siswanya, karena siswa akan lebih memahami serta memiliki keinginan untuk mengikuti pelajaran yang disampaikan oleh guru tersebut. Hal ini sesuai dengan yang diungkapkan oleh Y, U, S, NR, K, MR sebagai berikut;

"...ya...diperlukan..." (Y)

"...karena komunikasi nonverbal itu bagian komunikasi yang menegaskan komunikasi verbal kita...” (Y) “...ya...komunikasi nonverbal sangat diperlukan ketika mengajar...” (U)

"...karena itu merupakan bahasa penekanan untuk menjelaskan pelajaran yang disampaikan..." (U)

“... sangat diperlukan...” (S)

“...karena kalau kita berkomunikasi secara lisan tidak ada kontak fisik kurang menarik, lebih menarik supaya mempertegas kalimat kita yang secara lisan..." (S)

“...sangat perlu...” (NR)

“...karena kalau misalnya pelajaran itu sangat penting dia menegaskan dengan cara menggunakan mata dan gerakan...” (NR)

“...perlu..." (K)

“...tanpa ada gerakan kita tidak tau pasti tentang pelajaran itu..." (K)

“...уа..." (MR)

"...karena komunikasi nonverbal bisa juga membantu siswa untuk menerima informasi yang disampaikan oleh guru, informasi yang disampaikan secara verbal..." (MR).

\section{Penggunaan Kinesik}

\section{Gerak isyarat (Gestures)}

Pada saat guru mengajar ternyata menggunakan isyarat tangan, isyarat digunakan agar pada saat guru menjelaskan pelajaran siswa siswi dapat mengerti pesan yang diberikan oleh guru. Namun isyarat tangan yang digunakan oleh guru dilakukan tergantung situasi dan kondisi dari siswa siswinya. Seperti yang diungkapkan oleh Y, U dan S sebagai berikut;

“...iya..agar anak mengerti..." (Y)

“...ya ada menggunakan isyarat tangan ada pake mulut melihat situasi dan kondisi ya kan anaknya..." (U)

"...saat menjelaskan terkadang saya menggunakan isyarat tangan..." (S)

Siswa siswi pun berpendapat sama, bahwa pada saat mengajar guru melakukan gerakan isyarat baik tangan ataupun tubuh, hal itu dilakukan agar siswa dapat fokus dalam memperhatikan guru yang sedang menerangkan pelajaran. siswa pun merasa tidak hanya komunikasi verbal yang menggunakan kata-kata melalui tulisan dan bahasa saja yang diperlukan, namun siswa pun merasa isyarat tangan dan tubuh dibutuhkan. Hal ini diungkapkan oleh NR, K dan MR sebagai berikut; 
“...ya..sepertinya ya soalnya karena untuk melakukan pergerakan atau gak body language nya itu agar lebih mudah dimengerti..." (NR)

“...iya menggunakan...karena terkadang itu kan gerakan refleks..." (K)

“...dalam kegiatan pembelajaran pasti memerlukan yang namanya komunikasi baik itu verbal maupun nonverbal memang dalam kenyataannya tidak semuanya namun itu juga diperlukan..." (MR)

Dengan menggunakan isyarat tangan akan memahami pelajaran yang diberikan oleh guru, karena isyarat tangan merupakan penguatan makna dari kata-kata yang diucapkan oleh guru. misalnya pada saat guru mengucapkan kata lingkaran maka secara otomatis tangannya akan membentuk lingkaran. Hal ini seperti yang diungkapkan oleh Y, U, dan S sebagai berikut;

"... saya rasa iya...karena kan pada saat memberikan materi tangan saya secara otomatis mencoba untuk menggambarkan maksud dari apa yang saya ucapkan...” (Y)

"...menurut saya iya memahami soalnya isyarat tangan kita kan menggambarkan sesuatu..." (U)

"...iya memahami...selain mendengarkan biasanya siswa juga melihat kita jelasin materinya..." (S)

Siswa pun merasa demikian, dengan adanya gerakan isyarat tangan yang diberikan guru pada saat menerangkan pelajaran, membuat mereka lebih memahami apa yang dimaksudkan oleh guru tersebut, hal ini dapat dilihat dalam kutipan wawancara berikut ini;

“...kalo gurunya diem aja...mana la paham..."(NR)

“...iya lebih memahami..." (K)

“...lebih menarik kalo guru mengajar pake isyarat tangan...lebih mengerti (MR)

Isyarat tangan dan tubuh yang dilakukan oleh guru dalam mengajar terkadang dilakukan tanpa disadari. Isyarat tangan dan tubuh yang dilakukan guru tanpa disadari ini contohnya mengipasngipas karena kondisi cuaca yang panas. Ada juga yang menyatakan bahwa gerakan isyarat tangan dan tubuh yang dilakukan tanpa disadari akibat dari rasa grogi pada diri guru karena kehabisan bahan dalam mengajar siswa-siswinya, selain itu ada juga akibat dari kondisi kesehatan seorang guru yang kurang baik sehingga menyebabkan isyarat tangan dan tubuh terjadi tanpa disadari oleh guru tersebut. Seperti yang diungkapkan oleh $\mathrm{Y}, \mathrm{U}$ dan $\mathrm{S}$ berikut ini:

"...pernah..." (Y)

“...ya itu bisa saja terjadi karena apa karena kadang-kadang seorang guru itu bisa kehabisan bahan ataupun dia itu menghadapi masalah sehingga ya...dia lupa apa yang mau disampaikan gitu jadi bisa saja dalam bentuk grogi bisa juga orang kurang menguasai bahan ataupun situasi kesehatannya bisa juga tidak mendukung..." (U)

“...ya sesekali pernah juga seperti ya mungkin karena panas kan di lokasi kelas jadi terkadang tanpa sengaja mengipas-ngipas..." (S)

Siswa-siswi menyadari bahwa ada gerakan isyarat tangan dan tubuh yang dilakukan tanpa disadari terutama pada saat guru mengajar. Mereka menyebutnya sebagai gerakan reflex, seperti kutipan wawancara berikut ini;

“...ya ini juga kadang tanpa kita sadari juga terlakukan karena ini ada kayak ada gerakan refleks gitu jadi kalau ada gerakan sikit itu tanpa kita sadari...kadang-kadang gitu...” (NR)

“...pernah lha..itu kan kadang digerakinnya otomatis gitu...” (K)

“...iya...iya sebenernya iya...” (MR)

\section{Ekspresi Wajah}

Kondisi emosi seorang guru dapat terlihat dari ekspresi wajahnya, melalui ekspresi wajah inilah siswa-siswinya dapat melihat dan menilai apakah guru sedang dalam kondisi marah, senang atau gembira. Pada guru yang menjadi informan peneliti menyatakan bahwa mereka menunjukkan kondisi emosi mereka pada saat mengajar melalui ekspresi wajahnya, baik itu emosi marah, gembira ataupun sedang merasa tidak nyaman. Hal tersebut diungkapkan seperti yang berikut ini; “...уа..."(Y) 
“...ya itu bisa kenapa gitu karena setiap orang ya bisa mengetahui bentuk forum wajah seseorang gitu apakah dia senang, apakah dia benci, apakah dia marah untuk menghindari supaya jangan terjadi istilahnya kontak fisik dengan murid sehingga kita terhindar dari hukum..." (U)

"...ya dalam mengajar terkadang saya juga menunjukkan kondisi emosi ekspresi wajah yang sesekali kita tunjukkan kegembiraan ataupun kadang marah..." (S)

Siswa siswi pun menyadari bahwa guru menunjukkan emosi marah atau senang melalui ekspresi wajahnya. Namun ada juga guru yang memberikan kesan diamnya tanpa ada kata-kata atau bahasa yang dikeluarkannya memberikan tanda bahwa ia sedang marah terhadap siswa-siswinya di dalam kelas, seperti yang diungkapkan oleh NR dan MR berikut ini: ah terhadap siswa-siswinya di dalam kelas, seperti yang diungkapkan oleh NR dan MR berikut ini;

“...terkadang kalo guru lagi marah kita bisa ketahui dari mimik mukanya gitu..kalo dia lagi marah diem...diem aja...kalau kita buat salah dia diem aja...jadi kita tahu kalo dia diem aja artinya dia lagi marah..." (NR)

“...iya ada...kadang kalo lagi nyuruh kami diem mukanya rada galak gitu...” (K)

“...iya...” (MR)

Untuk menunjukkan ekspresi wajah maka siswa siswi akan lebih tertarik dalam mengikuti pelajaran. apabila guru masuk ke kelas kemudian memberikan materi dengan ekspresi yang tidak menyenangkan maka siswa siswi yang menerima pelajaran pun akan merasa tidak tertarik. Sehingga mereka tidak terlalu memperhatikan materi yang diajarkan. Namun apabila wajah guru cerah dan ceria pada saat masuk dan menerangkan materi, maka siswa akan semangat dan tertarik dalam mengikuti materi yang diajarkan hal ini sesuai dengan apa yang diungkapkan oleh para guru dan siswa berikut ini:

“...iya pastinya bayangkan saja kalo seandainya ekspresi wajah saya cemberut atau menakutkan apa iya siswa mau belajar...paling Cuma belajar belajar gitu aja...tapi nggak punya minat..." (Y)

“...iya...pada saat kita ngajar dengan memberikan wajah bersahabat atau wajah penuh senyuman maka siswa akan tertarik dalam mengikuti pelajaran..." (U)

"...ya pasti mereka tertarik la kalau wajah kita nggak ditekuk...kalo ditekuk kesannya seram..." (S)

"...kalau guru ekspresinya menyenangkan belajar pun jadi enak..." (NR)

“...iya lebih tertarik..." (K)

“...belajar jadi semangat kalau ekspresi guru ceria, kaau nggak ya bisa jadi bosan...” (MR)

Pada saat proses belajar mengajar berlangsung guru lebih banyak memberikan ekspresi wajah senang dan kegembiraan dibandingkan ekspresi wajah marah atau menakutkan. Hal tersebut dilakukan agar tidak merasa bosan dalam menerima pelajaran dan juga diharapkan siswa siswi tidak mengantuk pada saat belajar di kelas. Hal ini seperti yang diungkapkan oleh Y dan S berikut ini;

“...emosi kegembiraan..." (Y)

“...yang sering saya tunjukkan itu ekspresi wajah dalam kegembiraan karena dalam menjelaskan juga supaya anak-anak itu tidak bosan tidak ngantuk makanya ekspresi wajah yang menggembirakan yang saya tunjukkan..." (S)

Menurut U perhatian kepada siswa siswi jangan sampai terlepas, siswa siswi harus terus di perhatikan. Hal ini dapat diambil kesimpulan bahwa U lebih banyak memberikan kesan serius pada ekspresi wajahnya, seperti petikan wawancara berikut ini;

“...bisa, jangan terlepas kepada anak...”(U)

Kondisi emosi yang paling sering siswa siswi lihat pada saat guru mengajar antara lain emosi marah apabila kelas dalam kondisi ribut, dapat dicontohkan bahwa guru yang sedang cemberut atau melotot berarti gurunya sedang marah. Selain itu emosi senang juga ditunjukkan oleh guru dengan cara menunjukkan ekspresi senyuman, namun bagi MR dengan gurunya tersenyum saja bukan berarti gurunya memiliki rasa kegembiraan namun bisa saja ada hal lain yang 
dirasakan oleh hatinya. Seperti yang diungkapkan oleh NR dan MR dalam kutipan wawancara berikut ini;

“...eee...ekspresi marah...terkadang...oh ya...mukanya kayak yang cemberut matanya melotot waktu anak muridnya pada ribut gitu waktu dia lagi menerangkan itu paling diiniin ama guru..." (NR)

“...ekspresi yang sering diperlihatkan...ekspresi senyum...marah terkadang-kadang dan juga ekspresi yang mungkin kita tidak ketahui sebenarnya karena terkadang ada guru ya..ekspresinya senyum tapi dalam hatinya ada yang mengganjel gitu..." (MR) Sedangkan pada K ekspresi wajah yang paling sering ditunjukkan oleh guru pada saat mengajar antara lain ekspresi yang menenangkan. Terutama pada saat kelas dalam kondisi ribut. Hal ini diungkapkan oleh $\mathrm{K}$ berikut ini;

“...apabila misalnya anaknya ribut pasti dia caranya menenangkan gitu...." (K)

\section{Kontak Mata}

Kontak mata dalam proses belajar mengajar sangat diperlukan, karena dengan adanya kontak mata maka keseriusan dalam berkomunikasi akan terjalin sehingga perhatian siswa siswi terhadap guru didapatkan. Apabila siswa siswi sudah memiliki perhatian terhadap guru yang sedang menerangkan pelajaran di depan kelas maka pelajaran itu pun akan diterima dengan baik oleh siswa siswi tersebut. Melalui kontak mata dengan siswa siswi juga dapat mencerminkan bahwa seorang guru pun mengharagai siswa siswinya. Hal ini diungkapkan oleh Y, U, S dalam kutipan wawancara berikut ini;

“...ya...diperlukan..." (Y)

“...iya itu sangat penting kali karena di dalam ilmu retorika salah satu diantaranya kalau kita berbicara dengan seseorang harus serius kita melihat menanggapinya itu berarti kita itu sangat fokus dan sangat menghargai dia sebagai siswa..." (U)

"...ya sangat perlu Pak karena kan kalo kita dalam tahap menerangkan mungkin kalau tidak ada kontak mata jadi anak itu pun perhatian kepada kita tidak terfokus..." (S)

Dalam kondisi menerangkan pelajaran di depan kelas terdapat hal-hal yang menyangkut dengan kontak mata antara lain ada yang melakukan kontak mata langsung kepada siswa siswinya, namun ada juga kontak mata tidak langsung ditujukan kepada siswa siswinya tapi mata guru lebih terfokus pada buku ataupun papan tulis saja. Pada guru di SMP Muhammadiyah 7 ini kontak mata dilakukan langsung pada siswa, karena apabila kontak mata tidak langsung ditujukan kepada siswa maka siswa siswi dapat beranggapan bahwa guru tidak mampu serta tidak menguasai mata pelajaran yang diajarkannya sehingga guru harus lebih terfokus dalam penguasaan muridnya. Hal ini seperti yang diungkapkan oleh $\mathrm{Y}, \mathrm{U}$ dan $\mathrm{S}$ dalam petikan wawancara berikut ini;

"...kontak mata ditujukan pada siswa..." (Y)

“...jadi kita dalam komunikasi menjadi seorang guru kita harus menguasai pelajaran apabila kita menguasai pelajaran apalagi guru yang sudah lama tentu dia sudah menguasai pelajaran dan dia harus lebih fokus kepada penguasaan murid..." (U)

“...melakukan kontak mata dengan siswa..ya..." (S)

Kontak mata yang dilakukan guru pada saat memberikan materi di kelas akan menimbulkan rasa perhatian guru terhadap siswa yang sedang belajar. Dengan merasa diperhatikan dalam belajarnya siswa siswi pun akan merasa terpacu lagi dalam menaikkan prestasi mereka. Hal ini sesuai dengan kutipan wawancara dari Y, U, S, NR, K, dan MR berikut ini;

“...tentu saja merasa diperhatikan...biasanya yang namanya siswa itu kalau dia merasa diperhatikan maka semangat belajarnya akan tumbuh..." (Y)

“...iya merasa diperhatikan..." (U)

"...kontak mata itu kan perlu...itu menandakan kalau kita perduli dengan siswa..." (S)

"...kalo guru liat kita berarti diperhatikan kalo gak liat bearti gurunya cuek-cuek aja..." (NR)

"...ya merasa diperhatikan..." (K)

“...berarti kan belajar kita diperhatikan kalo ada kontak mata...” (MR) 
Menurut siswa siswi guru melakukan kontak mata langsung kepada siswa siswinya, walaupun posisi guru sedang menulis di papan tulis tetapi matanya tetap mengawasi siswanya. Dengan melakukan kontak mata langsung terhadap siswa siswinya akan menunjukkan perhatian guru dalam mengajar. Hal ini diungkapkan oleh NR, K, dan MR pada kutipan wawancara berikut ini: “...tidak kayaknya tertuju pada semua anak-anak muridnya karena dia melihat kondisi anak muridnya itu eee...sedang apa pas dia menerangkan gitu karena kan untuk ini juga..." (NR)

“...ee..ya kan..gurukan menulis sambil melihat kayak mana anaknya itu paham atau tidak..." (K)

“...guru lebih baik fokus pada siswa-siswanya kontak mata terhadap siswa..." (MR)

\section{Penampilan}

Penggunaan baju dalam mengajar merupakan salah satu yang penting dalam menunjukkan identitas seorang guru. Terdapat sekolah yang menyediakan seragam sekolah untuk para gurunya, biasanya sekolah tersebut ingin menunjukkan identitas asli dari sekolahnya. Namun ada juga yang tidak menyediakan seragam sekolah untuk guru yang mengajar disekolah tersebut. Pada sekolah SMP Muhammadiyah 7 Medan ini pakaian seragam untuk guru disediakan oleh pihak sekolah tetapi seragam ini hanya digunakan untuk hari-hari tertentu yang sudah ditetapkan oleh pihak sekolah, dan ada juga hari-hari dimana guru dibebaskan dari pemakaian baju seragam. Hal ini sepeti yang diungkapakan oleh Y, U, dan S pada kutipan wawancara berikut ini;

"...disediakan pihak sekolah..." (Y)

“....ada yang disediakan ada yang tidak, kadang-kadang disediakan kadang-kadang tidak..." (U)

“...disediakan oleh pihak sekolah..." (S)

Menurut siswa siswi baju seragam digunakan pada hari-hari tertentu saja, karena ada satu waktu guru menggunakan baju bebas dalam mengajar. Baju seragam yang digunakan oleh guru sudah baik, sopan dan rapi pada saat dikenakan oleh para guru. Hal ini diungkapkan oleh NR, K, dan MR pada kutipan wawancara berikut ini;

“...kadang ada juga eee...guru yang seragam di hari-hari tertentu dan ada juga bebas aja pake baju apa aja..." (NR)

“...baik..sopan..." (K)

“...sudah bagus..sudah rapi...” (MR)

Baju seragam juga harus bisa disesuaikan dengan tatanan rambut atau jilbab yang dikenakan oleh guru, penyesuaian tersebut dilakukan agar penampilan dapat lebih menarik. Penyesuaian ini dilakukan oleh $\mathrm{Y}$ dan $\mathrm{S}$, pada $\mathrm{Y}$ warna jlbab akan disesuaikan dengan warna bajunya sedangkan pada $S$ tatanan rambutnya akan selalu rapi sehingga pada saat ia menggunakan baju yang bagaimanapun maka tetap akan sesuai dan rapi. Hal ini seperti yang diungkapkan oleh $\mathrm{Y}$ dan S dalam kutipan wawancara berikut ini;

"...disesuaikan warna pakaian dengan jilbab..." (Y)

“...menyesuaikan rambut itu yang jelas ya saya rapi walaupun model baju warna baju yang bagaimana tetap rapi

satu sekolah saja sehingga untuk mengganti baju yang kemudian disesuaikan dengan tatanan rambut dirasa tidak memungkinkan. Hal ini seperti yang diungkapkan dalam kutipan wawancara berikut ini: ..." (S)

Namun pada $\mathrm{U}$ penyesuaian antara pakaian denga rambut tidak dianggap serius, karena tempat mengajarnya tidak hanya satu tempat saja.

“...dari situ kita tidak mengatur begitu serius kenapa karena kadang-kadang pakaian yang kita mengajar itu bukan hanya satu tempat kadang-kadang dua tempat sedangkan bajunya cuma satu yang kita pake kalau kita tukar baju itu kan susah..." (U)

Baju yang digunakan oleh guru disaat mengajar sudah sesuai dengan tatanan rambut dan jilbabnya. Penampilan guru dimata siswa siswinya sudah sesuai dan rapi sehingga enak dipandang. Hal ini seperti yang diungkapkan oleh NR, K, dan MR pada kutipan wawancara berikut ini;

“...ya kayaknya sesuai...” (NR) “...eee... itu semua sesuai...” (K)

“...iya sudah tepat..." (MR) 
U dan S selaku guru yang mengajar di SMP Muhammadiyah 7 Medan ini menggunakan parfume atau wangi-wangian sebelum berangkat ke sekolah, sehingga pada saat mengajar akan menimbulkan aroma yang menyenangkan. Seperti yang diungkapkan U dan S pada kutipan wawancara berikut ini;

“...ketika mengajar tidak menggunakan parfume tapi sebelum kita berangkat ke sekolah kita sudah gunakan parfume...”(U) “...уа..." (S)

Pada Y, beliau tidak menggunakan parfume pada saat akan berangkat ke sekolah seperti yang diungkapkan oleh Y berikut ini;

“...tidak..." (Y)

Para siswa lebih menyukai guru yang menggunakan parfume atau wewangian pada saat mengajar di kelas, karena dengan aroma yang wangi akan membangkitkan semangat siswa dalam belajar, kemudian juga dapat membuat perasaan siswa lebih baik saat berada di dalam kelas. hal ini seperti yang diungkapkan oleh NR, K, dan MR dalam kutipan wawancara berikut ini;

"...kayaknya parfume tha soalnya khan kalo keadaan kita lagi gak mood gitu terus nyium yang gak gak enak trus kita langsung bad mood..ya kan soalnya wangi kalo deket..." (NR)

“...eee..lebihnya sih iya soalnya kan di ruangan itu biar lebih agak wangi gitu..." (K)

"...lebih suka yang memakai parfume...karena guru yang memakai parfume itu memiliki ke khasannya sendiri dalam berpakaian...karena Rasul sendiri sudah mengajarkan kita untuk memperhias diri kita... salah satunya berparfume lha..." (MR)

Penampilan yang rapi dan wangi tentu saja memiliki kesan tersendiri dalam berinteraksi. Apalagi yang berperan dalam proses belajar mengajar, kaena guru akan berada di depan kelas untuk menjelaskan materi pelajaran, dan siswa menjadi audience nya sehingga perhatian siswa siswi akan tertuju semata-mata ke satu arah. Sehingga kerapian dan aroma guru yang wangi akan menarik perhatian siswa, kalau sudah mulai nyaman dengan gurunya maka siswa siswi pun akan dengan senang hati mengikuti pelajaran yang diberikan oleh guru. hal ini seperti yang diungkapkan oleh Y, U, S, NR, K, dan MR berikut ini:

“...tentu saja bisa membangkitkan semangat belajar siswa...contohnya saja kalo warna baju saya tabrakan...kira-kira enak gak siswa siswinya liat saya waktu saya lagi nerangin materi....nggak kan...konsentrasi gak mereka jadinya...nggak kan...trus kalo saya nggak wangi atau tercium aroma keringet... siswa juga nggak ada yang mau deket-deket sama saya..." (Y)

“...kan kalo guru rapi dipandang siswa enak...kalo wangi siswa pun suka jadi siswa pun tidak merasa terganggu dengan aroma bau badan pada saat berdekatan untu menanyakan sesuatu..." (U)

"...iya membangkitkan semangat siswa...karena anak-anak akan merasa nyaman kalo liat saya sedang mengajar..." (S)

“...iya kan enak di pandang...pelajaran pun jadi masuk...” (NR)

“...tentu saja iya...kalo nggak rapi kami pun gak semangat...kesannya kayak apa gitu...”(K)

“...kalo guru rapi kesannya itu kan dia serius ngajar kita...kita pun jadi serius juga la belajarnya..." (MR)

\section{Proksemik Jarak}

Dalam proses belajar mengajar guru menjaga jarak dengan siswa terutama pada saat guru sedang mengalami emosi marah. Bagi seorang guru antara guru dengan siswa tetap harus selalu menjaga jarak agar penilaiannya terhadap para siswa menjadi nilai yang objektif dan bukan penilaian secara subjektif. Seprti yang diungkapkan pada kutipan wawancara berikut ini;

“...nggak jaga jarak...kadang-kadang pada saat saya nerangin materi pelajaran saya berjalan mendekati siswa ..." (Y)

“... sebenarnya melihat situasi dan kondisinya seandainya kita lagia agak emosi kita harus menjaga jarak kita jangan terlalu dekat dengan siswanya, ya...sekitar satu meter...” (U)

“...ya jaga jarak...2 meter..." (S) 
Berbeda dengan yang dirasakan oleh siswa, menurut siswa guru tidak menjaga jarak dengan mereka, bagi mereka apabila guru menjaga jarak dengan siswa maka mereka akan takut dan segan untuk bertanya tentang pelajaran. seperti yang diungkapkan oleh NR dan K dalam kutipan wawancara berikut ini;

“...sepertinya tidak karena kalo jaga jarak ee...komunikasi itu susah jadi takut takut siswanya untuk menanyakan sesuatu pada guru..." (NR)

“...tidak..." (K)

Namun bagi MR guru memang menjaga jarak dengan siswanya, seperti yang diungkapkan oleh MR berikut ini:

“...ya itu benar...” (MR)

Dalam belajar mengajar interaksi antara siswa dengan guru sangat diperlukan agar pelajaran yang diterima siswa dapat efektif. Menurut para guru terdapat siswa yang bertanya langsung ke meja guru apabila mengalami kesulitan tentang pelajaran yang tidak dimengertinya, hal ini menunjukkan interaksi antara guru dan siswa dinilai baik. Seperti yang diungkapkan oleh Y, $\mathrm{U}$ dan S dalam kutipan wawancara berikut ini;

"....ada..." (Y)

“...ya ada...ada yang langsung..." (U)

“....ada..sesekali ada..." (S)

Siswa juga menganggap bahwa interaksi guru akan dinilai baik apabila terdapat siswa yang bertanya langsung ke meja guru untuk menanyakan pelajaran yang tidak dimengertinya, sehingga siswa siswi pun pernah bertanya langsung ke meja guru mereka. Seperti yang diungkapkan oleh NR, K, dan MR dalam kutipan wawancara berikut ini;

“...ohhh...pernah...” (NR)

“...pernah..." (K)

“...iya saya pernah..." (MR)

Selain murid yang datang langsung ke meja guru pada saat terdapat pelajaran yang tidak dimengerti ternyata gurupun melakukan hal yang sama terhadap siswa siswinya, para guru akan mendatangi meja dari siswanya yang tidak mengerti yang kemudian akan menjelaskan ulang tentang pelajaran yang tidak dimengertinya. Seperti yang diungkapkan oleh Y, U dan S dalam kutipan wawancara berikut ini;

“...pernah..." (Y)

“...ya jelas ada..." (U)

"...iya...di datangi..." (S)

Begitu juga dengan siswa, siswa merasa diperhatikan pada saat guru mendatangi meja mereka apabila mereka tidak mengerti tentang pelajaran yang diterangkan tersebut. Menurut NR dengan guru mendatangi meja siswa maka akan membantu siswa lain yang kurang memiliki kemampuan dalam mendekatkan diri pada guru, dan hal ini merupakan sesuatu yang penting. Seperti yang diungkapkan oleh NR, K dan MR dalam kutipan wawancara berikut ini:

“...ya pernah itu pun penting juga bagi guru ya kan karena kalo siswanya kurang mampu tuk mendekatkan diri kepada gurunya...gurunya yang mendekatkan diri untuk menanyakan apa saja yang gak diketahui kepada muridnya itu..." (NR)

\section{Prosemik Ruang}

\section{a. Ukuran Ruang}

Ukuran suatu kelas sangat pentingdalam menampung jumlah siswa dalam mengajar, karena berdasarkan ukuruan ruang kelas ini lah nanti menjadi salah satu tolak ukur kenyamanan siswa dalam belajar. Tetapi apakah para guru mengetahui pasti berapa besar ukuran ruang kelas tempat mereka mengajar dan ternyata beragam jawaban yang disebutkan oleh para informan seperti kutipan wawancara berikut ini; 
“..66 6 meter..." (Y)

“...7 x $8 \ldots ”(\mathrm{U})$

“...ukuran mengajar kira-kira 10 meter...ooo...ruang kelas kira-kira 8 meter..." (S)

Bagi para guru ruangan kelas tempat mereka mengajar kini sudah cukup besar dan memenuhi standart dalam menampung jumlah siswa sebanya 32 orang. Dengan kondisi kelas yang cukup besar ini siswa siswi dirasa nyaman untuk melakukan proses belajar mengajar. Seperti yang diungkapkan oleh Y, U dan S dalam kutipan wawancara berikut ini;

“...cukup besar...”(Y)

“...7 x 8 sudah disesuaikan dengan jumlah murid, jumlah murid yang ideal itu mungkin 32 ya kan...cukup besar..." (U)

“... saya rasa cukup standart Pak...” (S)

Bagi siswa siswi pun beranggapan sama bahwa kelas yang mereka tempati sekarang ini sudah cukup besar untuk dijadikan tempat proses belajar mengajar, terutama dalam hal jangkauan siswa seperti sekolah di SMP Muhammadiyah 7 Medan ini. seperti yang diungkapkan oleh NR, K dan MR dalam kutipan wawancara berikut ini;

“...cukup besar...” (NR)

“...cukup untuk memadai..." (K)

“... sebenernya cukup besar untuk jangkauan siswa seperti di sekolah kita ini..." (MR)

Besar atau kecilnya suatu kelas mempengaruhi kualias belajar siswa karena apabila ukuran ruang kelas kecil sedangkan siswanya banyak maka kondisi siswa akan menumpuk dikelas. Pada kondisi seperti inimaka kegiatan belajar mengajar tidaklah akan efektif, dan kalau sudah tidak efektif maka kualitas dari belajar siswa akan menurun. Hal ini sesuai dengan yang diungkapkan Y, U, S, NR, K, dan MR pada kutipan wawancara berikut ini;

“...pengaruh la...ruang kelas kecil trus jumlah siswa banyak...proses belajar mana mungkin bisa efektif, kalau udah tidak efektif pasti akan mempengaruhi kualitas anak dalam belajar...” (Y).

\section{b. Hawa atau udara dalam ruangan}

Udara di dalam ruangan kelas SMP Muhammadiyah 7 Medan ini ada yang panas dan ada yang tidak, hal ini juga tergantung dari masing-masing ventilasi kelasnya dan juga tergantung dari fasilitas kipas angin yang disediakan sekolah apakah menyala atau tidak. Apabila kipas anginnya nyala maka kondisi ruangan kelas akan sejuk tetapi apabila kipas anginnya dalam kondisi mati maka hawa atau udara dalam ruangan akan panas. Seperti yang diungkapkan oleh Y, U dan S dalam kutipan wawancara berikut ini;

“...panas..." (Y)

“...ya kalau tergantung sekolah yang kita mengajar kalau disekolah itu ada ventilasinya cukup maka itu...kalau di SMP kita ini ada yang panas ada yang tidak karena tergantung dengan ventilasi udara..." (U)

“... sejuk karena dilengkapi dengan kipas angin..."

Begitu juga dengan pendapat siswa, apabila fasilitas kipas angin atau AC ada yang mati atau dalam kondisi mati lampu maka hawa atau udara dalam kelas akan terasa panas. Seperti kutipan wawancara pada NR, K dan MR berikut ini:

“...tergantung..tergantung cuacanya..mati lampu panas juga...” (NR)

"...kalo kipas angin mati tentunya panas..." (K)

“...tidak..." (MR)

Untuk ventilasi yang ada di kelas-kelas SMP Muhammadiyah ini masih ada yang kurang. Namun sebagian besar ventilasi yang terdapat pada masing-masing kelas sudah mencukupi sehingga udara yang keluar masuk melalui ventilasi lancar. Seperti yang diungkapkan oleh U dan S dalam kutipan wawancara berikut ini: 
“...kalau kita rasakan di SMP 7 ini ada kelas yang cukup ada yang kurang..."(U)

“...mencukupi Pak..." (S)

Begitu juga dengan siswa siswi, menurut mereka ventilasi yang ada dikelas mereka sudah cukup baik atau mencukupi sehingga pertukaran udara melalui ventilasi lancar. Hal ini diungkapkan oleh NR, K, dan MR berikut ini;

“... sepertinya cukup..." (NR)

“...cukup..." (K)

“... saya rasa cukup..." (MR)

Fasilitas untuk menyejukkan udara sudah disediakan oleh pihak sekolah, fasilita tersebut antara lain kipas angin dan AC. Namun AC hanya ada pada kelas yang full day sedangkan untuk kelas yang biasa hanya disediakan kipas angin saja. Seperti yang diungkapkan oleh U, S, NR, K, dan MR dalam kutipan wawancara berikut ini:

“...ada di full day ada AC kemudian regular hanya kipas angin..." (U)

“...iya ada..." (S)

“...dua-dua nya ada..." (NR)

“...kipas angin....kipas angin dua ada yang satu lagi tiga" (K)

“...ada..." (MR)

Hawa dan udara yang panas akan membuat konsentrasi siswa siswi akan tidak konsentrasi, hal ini terjadi dikarenakan siswa siswi bisa sibuk sendiri untuk mendinginkan badannya dengan cara mengipas-ngipaskan buku atau tangannya. Fasilitas yang baik dalam sekolah adalah dengan memberikan sarana dan prasarana agar siswa nyaman berada di kelas. hal ini dapat dilihat dalam kutipan wawancara berikut ini;

“... sebenernya sih nggak konsentrasi ya...ada yang kipas-kipas...trus ada juga yang nggak bisa diem badannya...jadi ya kurang juga itu konsentrasinya..." (Y)

“...kalau panas jelas anak tidak bisa konsentrasi..." (U)

"...saya rasa tidak bisa berkonsentrasi soalnya sibuk berkipas..." (S)

"...gak konsentrasi...kipas-kipasan terus..." (NR)

“...ya gak bisa konsentrasi kalo panas...” (K)

"...gak bisa konsentrasi..." (MR)

\section{c. Warna}

Warna yang dimaksud di sini merupakan warna cat dinding pada kelas yang dipergunakan untuk proses belajar mengajar antara siswa siswi dengan gurunya. Pada warna cat dinding kelas di sekolah SMP Muhammadiyah 7 Medan para informan menyebutkan beragam warna ada yang menyebutkan warna putih, hijau dan kuning. Namun pada dasarnya maksud dari para informan tersebut bahwa warna cat dinding kelas merupakan warna yang cerah. Hal tersebut diungkapkan oleh Y, U, S, NR, K, dan MR pada kutipan wawancara berikut ini:

“...hijau..."(Y)

“... warna itu sebenarnya adalah kalau netral itu adalah warna putih, kalau di dalam kelas kita itu warna biru atau warna hijau..." (U)

“...kuning..." (S)

“...hijau..." (NR)

“...warnanya hijau..." (K)

“...hijau..." (MR) 
Warna cat dinding ternyata memiliki makna tersendiri dalam diri masing-masing orang, dan juga dapat membawa pengaruh pada suasana hati seseorang. Begitu juga suasana kelas akan dipengaruhi oleh warna cat dinding yang digunakan sekolah. Menurut informan cat dinding yang ada dikelas menggambarkan kegembiraan, persahabatan, dan kesucian. Karena cat dinding kelas merupakan warnanya cerah sehingga suasana kelaspun menjadi ceria serta memiliki rasa semangat dalam menyerap ilmu pengetahuan yang diberikan oleh para guru. Seperti yang diungkapkan oleh Y, S, NR, K, dan MR dalam kutipan wawancara berikut ini:

“...kegembiraan dan bersahabat..." (Y)

“...kegembiraan..." (S)

“...ya kayaknya sepertinya itu juga ee...tertarik karena khan kalo item kan gimana gitu kalo belajar gitu gak enak kalo belajar warna cetnya itu gak kayak pendapat hati gitu...” (NR)

“...sudah... soalnya kan warnanya terang...” (K)

"...menurut saya tidak karena tidak lebih kepada persaudaraan atau persahabatan tetapi lebih pada kesucian..." (MR). Namun berbeda dengan pendapat informan U, ia menyatakan bahwa cat dinding yang ada di sekolah terutama di dalam kelas belum sempurna karena warna catnya masih belum rata sehingga masih ada warna-warna lain yang tersirat di dinding tersebut. Namun ia menyadari bahwa kekurangan tersebut dipengaruhi oleh dana. Sehingga menurut U suasana kelas belum begitu membawa kegembiraan dan persahabatan. Seperti kutipan wawancara berikut ini:

“... sebenarnya belum karena apa karena catnya itu belang-belang istilahnya itu kan belum lagi rapi pengecetannya seperti rumah-rumah yang memang punya uang yang cukup atau sekolah yang cukup pendanaannya..." (U)

Warna hijau yang melambangkan kegembiraan dan persahabatan ternyata memiliki pengaruh yang cukup besar dalam menciptakan kenyaman siswa dalam belajar di dalam kelas. Ternyata warna yang cukup terang seperti warna hijau sperti warna daun yang dapat menyejukkan mata. Hal ini sesuai dengan ungkapan pada kutipan wawancara berikut ini:

“...menurut saya bisa la membangkitkan semangat belajar siswa...kalau suasana cat kelasnya itu bisa membawa kegembiraan dan kebahagiaan...otomatis jiwa siswa pun akan merasa nyaman...kalo jiwa siswa udah nyaman, maka akan membangkitkan semangat belajar juga la..." (Y)

\section{Kesimpulan}

Komunikasi nonverbal guru yang berkaitan dengan kinesik antara lain; gesture, isyarat tangan, kontak mata serta penampilan yang digunakan guru dalam mengajar memiliki pengaruh yang cukup kuat terhadap siswa dalam memahami materi pelajaran, tertarik dalam mengikuti pelajaran, merasa diperhatikan pada saat belajar, danjuga membangkitkan semangat belajar siswa siswi. Pengaruh yang dihasilkan dari gerakan kinesik yang berupa gesture, isyarat tangan, kontak mata, serta penampilan ini dapat membawa siswa siswi meningkatkan prestasi belajarnya. Karena prestasi belajar merupakan ukuran keberhasilan kegiatan belajar siswa untuk menguasai mata pelajaran yang telah diterimanya selama periode tertentu yang biasanya dinyatakan dalam angka. Komunikasi nonverbal guru yang berkaitan dengan proksemik antara lain proksemik waktu, proksemik jarak, dan proksemik ruang, dapat meningkatkan prestasi belajar siswa, mempengaruhi kualitas siswa dalam belajar, mampu berkonsentrasi belajar di dalam kelas, membangkitkan semangat belajar siswa, dan memberikan kenyamanan belajar siswa di kelas. Dengan demikian komunikasi nonverbal yang menyangkut dengan proksemik apabila digunakan dengan benar, maka 
akan meningkatkan prestasi belajar siswa siswi SMP Muhammadiyah 7 Medan ukuran yang didapat adalah tercapai dan ditunjukkan seorang siswa sebagai bukti dari usahanya selama ini dalam hal belajar. Komunikasi nonverbal guru yang berkaitan dengan paralinguistik yang meliputi bentuk vokal, volume, kecepatan dan kualitas dapat membuat siswa siswi menerima, memahami dan menyerap materi pelajaran, sehingga siswa-siswi mampu belajar dengan baik dengan cara bantuan komunikasi nonverbal yang dilakukan oleh gurunya.

\section{Daftar Pustaka}

Ahmadi, Abu \& Widodo Supriyono. (2003) (edisi revisi). Psikologi Belajar. Jakarta: Rineka Cipta. Budyatna, Muhammad \& Leila Mona Ganiem. (2011). Teori Komunikasi Antarpribadi. Jakarta: Kencana Prenada Media Group.

Cangara, Hafied. (2002). Pengantar Ilmu Komunikasi. Jakarta: Raja Grafindo Persada.

Effendy, Onong Uchjana. (2003). Ilmu, Teori Dan Filsafat Komunikasi. Bandung: Citra Aditya Bakti.

Rosdakarya . (2008). Dinamika Komunikasi. Bandung: PT. Remaja

Hasrullah. (2013). Beragam Perspektif Ilmu Komunikasi. Jakarta: Kencana Media Group.

Kriyantono, Rachmad, 2006. Teknik Praktis Riset Komunikasi. Jakarta: Kencana Prenada Media Group.

Liliweri M.S. Alo. (2011). Komunikasi Serba Ada Serba Makna. Jakarta: Kencana Prenada Media Group.

Littlejohn, Stephen W. \& Karen A. Foss. (2014) (edisi 9). Teori Komunikasi. Jakarta: Salemba Humanika.

Lisna, Aris Maya, dkk. 2013. Pengaruh Komunikasi Guru-Siswa Terhadap Kemampuan Berpikir Kritis Pelajaran Ekonomi Siswa SMA Taman Mulia(jurnal vol. 2 No. 9) Pontianak: Universitas Tanjung Pura.

jurnal.untan.ac.id/indek.php/jpdpb/article/download/3469/3504/2013

Mulyana, Deddy. (2008). Ilmu Komunikasi Suatu Pengantar. Bandung: RemajaRosdakarya.

Morrissan. (2010). Psikologi Komunikasi. Bogor: Ghalia Indonesia. 